\title{
Performing unbelonging in court. Observations from a transnational corporate bribery trial-a dramaturgical approach
}

\author{
Isabel Schoultz ${ }^{1}$ D $\cdot$ Janne Flyghed ${ }^{2}$
}

Accepted: 13 September 2021 / Published online: 4 October 2021

(C) The Author(s) 2021

\begin{abstract}
This article presents a study of the theatrical performance in court in a high-profile transnational corporate bribery case. Data gathered from observations in court were supplemented with interviews with the defense teams and the presiding judge. The paper's objective is to demonstrate how the defendants performed unbelonging in court via the interactions between the different 'teams' in the courtroom; the defense, the prosecutors, the judges, and the company Telia. The analysis draws on Goffman's theater analogy and his understandings of performance and self-presentation. The authors introduce the concept of 'performing unbelonging in court' and show how the defendants performed unbelonging via an indirect expression of status and standing. The authors further analyze the defense teams' framing of the case, including the framing of the defendants as being scapegoated by the corporation, and of the prosecution as being unfair and illegitimate, which also contributes to the performance of unbelonging in court. The complexity and ambiguity of a transnational corporate bribery case permeated the interactions during the trial; however, at the end of the article, the authors discuss how knowledge from this case is transferable to other crime types or legal cultures.
\end{abstract}

\section{Introduction}

Corporate crime is often described as extremely complex, which makes everything from detection to the collection of evidence and securing convictions difficult for the justice system (Burns \& Meitl, 2020; Croall, 1993). Suspected crimes committed by

Isabel Schoultz

isabel.schoultz@soclaw.lu.se

Janne Flyghed

janne.flyghed@criminology.su.se

1 Department of Sociology of Law, Lund University, SE-Box 42, 22100 Lund, Sweden

2 Department of Criminology, Stockholm University, 10691 Stockholm, Sweden 
large corporations often require lengthy and very expensive investigations, where the criminal justice system may have less resources than financially powerful corporations (Beare \& Beare, 2018). If charges are brought, there are strong incitements to make a plea deal in countries such as the USA (Burns \& Meitl, 2020; Mann, 1988, p. 200). At the same time, prosecutors are not supposed to bring cases to court unless they are convinced they are very likely to result in a conviction (Bergman Blix \& Wettergren, 2018). These circumstances result in white-collar crime, including corporate crime, rarely being tried in court (Burns \& Meitl, 2020; Mann, 1988; Levi, 2017, p. 9).

When three former executives from the Swedish telecommunication company Telia were brought to trial in Sweden in September 2018, more than six years had passed since the start of the prosecutor's investigation. Since Telia entered Uzbekistan in 2008, the company's dealings have attracted a substantial amount of media attention and resulted in criminal investigations both in Sweden and abroad. In 2012, the so-called "Uzbekistan affair" was uncovered, which five years later resulted in a disgorgement (i.e. the surrender of profits obtained illegally from the Uzbek affair) and a global settlement in which Telia agreed to pay $\$ 965$ million to resolve charges relating to violations of the Foreign Corrupt Practices Act (FCPA) in the USA and of Dutch law (U.S. Department of Justice, 2017). The Telia-Uzbek scandal can be labeled transnational corporate bribery, described by (Lord et al., 2016, pp. 365-366) as involving commercial enterprises "that operate in transnational markets and use illicit (financial) transactions/exchanges to win or maintain business contracts in foreign jurisdictions." The day after Telia announced that a global settlement had been reached, the Swedish Prosecution Authority levelled criminal charges against the former CEO and two other senior company officials for their involvement in the company's bribery scheme in Uzbekistan. One important fact to bear in mind is that in Swedish law, there is no criminal responsibility for companies, only for individuals. In addition to the criminal charges against individuals, the Swedish prosecutors therefore also pursued Telia for disgorgement, in the same trial. The trial started at the Stockholm District Court on September 5th and lasted until December 19th, in total 42 days. The verdict was announced on February 15th, 2019; all three defendants were acquitted. The prosecutor appealed to the Court of Appeal and in February 2021 the defendants were also acquitted in the second instance. For a number of reasons, the case is unique, especially in a Swedish context. It involves representatives of a large corporation, and the Swedish government remains the company's principal shareholder, with almost $40 \%$ of the shares. The Telia case is transnational in several respects, involving alleged crimes committed by a Swedish corporation in Uzbekistan and criminal investigations in several countries. The case also involves large sums of money; the SEC estimated that Telia made at least $\$ 330$ million in illicit payments (Securities and Exchange Commission, 2017, p. 2). Finally, the legal case has been extensive, including the global settlement with American and Dutch authorities and a criminal investigation in Sweden, which took 6 years and resulted in a preliminary investigation protocol of almost 40,000 pages and over 40 days in court.

This study is an exploration of the Telia trial from the perspective of the theater of the courtroom. Data gathered from observations in court have been supplemented 
with interviews with the defense teams and the presiding judge. During the trial, we observed how the defense argued that the case and the defendants did not belong before the court. The performance of unbelonging ${ }^{1}$ in court goes beyond the claim of innocence and includes how the defendants acted and interacted with others both inside and outside the courtroom. The aim of the paper is to demonstrate how the defendants perform unbelonging in court via the interactions between the 'teams' in the courtroom; the defense, the prosecutors, the judges, and the company Telia. This is particularly interesting in relation to the fact that the trial concerns a transnational corporate bribery case, which has shaped how the performances of unbelonging in court played out. More explicitly, we ask: How did the defendants, with the support of their defense teams, perform unbelonging in court in relation to the particular type of crime being prosecuted, a transnational corporate bribery case?

The analysis builds on an understanding of 'performance' and 'presentation of self' (Goffman, 1959, 1974), where the court room is the stage. The concept of 'performing unbelonging in court' refers here to how defendants and the defense appear and intentionally present arguments in court that are intended to convince the audience that the defendants do not rightly belong in this situation. The performance of unbelonging is understood here as an attempt by the defense to strategically 'define out' the prosecuted individuals from the category 'defendants in a criminal trial'. The analysis will demonstrate that the defendants performed unbelonging in court in two main ways. First, the way in which the defendants carried themselves and expressed themselves frontstage and backstage signaled that they did not belong to the category of defendants in a criminal trial. Secondly, the defense's framing of the case, which included the claim of being scapegoated and arguments about the complexity of the case and about the prosecution being unjust, are understood here as another form of performing unbelonging in court. The defense definition of the situation was that the neither the case nor the defendants should have been brought to trial. These performances in court are closely related to business-related aspects of the trial, a transnational corporate bribery case involving a large corporation and three former executives. The analysis contributes with an understanding of constructions and negotiations focused on the definition of a situation in which individuals accused of economic crimes attempted to 'save face' (see Goffman, 1959, p.238) through a performance of unbelonging in a criminal trial after being "thrown to the wolves" (Jordanoska, 2021, p. 313). The interactional analysis contributes with an understanding of the tripartite relationship between the prosecutor, the individual defendants and the corporation (Jordanoska, 2021), with the judge "ensuring fair play" (Flower, 2018a, p. 227). The detailed analysis of courtroom interactions is a novel contribution to the white-collar and corporate crime literature since it chisels out the role of court performances in criminal proceedings involving business actors who are, on the one hand, well-resourced and of high social status, while on the other they are standing alone without the support of their former firm.

\footnotetext{
1 The concept of unbelonging is mainly used in another scholarly discussion, associated with citizenship, ethnic minorities and intersectional perspectives on (un)belonging in a community (e.g. Yuval-Davis, 2007).
} 


\section{Previous research}

Scholars have analyzed court hearings on the basis of Goffman's (1959, 1974) theater analogy and his understandings of performance and self-presentation (e.g. Bergman Blix \& Wettergren, 2018; Bens, 2018; Flower, 2018b). However, there is little literature based on court observations from white-collar or corporate crime trials (Pontell \& Geis, 2007). Much of the 'court ethnography' has focused on juveniles (e.g. Barrett, 2013; Emerson, 2008; Kupchik, 2006) and has in addition been conducted in the United States (Paik \& Harris, 2015), which has a different legal system and court culture from that of Sweden. The American legal system, in contrast to the Swedish, is characterized by a plea bargaining culture, not least in relation to white-collar crime (Mann, 1988; Askinosie, 1989). ${ }^{2}$ Kenneth Mann's (1988) Defending white-collar crime, is an interesting portrait of private white-collar crime attorneys at work in the United States. His thorough study shows how attorneys devote a substantial part of their work to the pre-charges stage, trying to control access to information, and make substantive legal arguments before the charge decision. At the sentencing stage, and of relevance to this study, another argument is often used, that of the defendant's exemplary record, and the suffering, in personal and professional life, already experienced by the defendant during the criminal justice process (Mann, 1988, p. 204, see also Croall, 1993). More recently, Walenta (2020) published a study on the courtroom ethnography of the criminal trial against former Enron chief executives from a critical spatial perspective within the legal geography tradition. She observed legal tactics and staged performances during the trial that provide insights into the embodied nature of the law in this particular high-profile court case. Based on data gathered from observations of criminal trials focused on insider-trading and market manipulation, as well as interviews with prosecuting and defense lawyers and a trial judge, Jordanoska (2017)has analyzed the efficient management of complex fraud cases. This requires judges to actively manage the trial as well as a cooperative attitude on the part of prosecutors and the defense, which thus affects the interactions between the actors in the court. Jordanoska found that the managerialist approaches, which were ultimately employed to reduce costs, curtailed adversarialism to some degree but that adversarial tactics were still used by both prosecutors and the defense during the pre-trial stage. In another publication, Jordanoska (2021) has explored the tripartite relationships and interactions between individual-firm, regulator-individual and regulator-firm, in organizational insider enforcement proceedings, based on observations of administrative decision making, interviews with stakeholders and documentary analysis. Here she shows the complexity of enforcement related to corporate failings, where individuals are more likely than firms to engage in adversarial responses in investigations since they have more to lose, while firms are more prone to settle based on their cost-benefit analyses. However, the interactions during the enforcement process will be affected by

\footnotetext{
${ }^{2}$ Plea bargains are not permitted in Sweden. However, summary sanction orders (strafföreläggande) constitute an option when the penalty is limited to fines and / or a conditional sentence if the accused has confessed.
} 
whether or not an individual is supported by the firm and has access to corporate resources.

The studies mentioned above all relate to common law systems and a legal culture that differs from that of Sweden. There are, however, studies that have focused on the dramaturgical aspects of the Swedish courtroom, although not with regard to business-related crime. These studies of professional actors in the Swedish courtroom take their point of departure, either fully or partly, in 'courtroom emotions' and the theater analogy (Bergman Blix \& Wettergren, 2018; Flower, 2018b; Törnqvist, 2017). They provide examples of the relevance of Goffman's dramaturgical approach in twenty-first century courtrooms. Törnqvist (2017, p. 294ff) discovered for example that prosecutors themselves use theater metaphors, talking about 'entering the stage', 'starting the show' 'entering into one's role' and being able to 'stay in character'. Flower (2018b, p. 55) notes, in her dissertation on defense lawyers in Swedish courtrooms, that the trial can be seen as "a three-team interplay: the defense, the prosecution and the judges. Similarly, Bergman Blix and Wettergren (2018, pp. 165-166) argue that when approaching the court as a theatre, we acknowledge that "the legal professionals all need to play their parts, and emotionally tune in and communicate both openly, with lay people, and tacitly, with each other". Both Bergman Blix and Wettergren (2018) and Flower (2018b) use Goffman's terminology of frontstage and backstage in the context of courts, where the courtroom represents the frontstage while the waiting room and chambers for prosecution and judges represent the backstage. We will now continue by elaborating our theoretical framework.

\section{The trial as theater: a dramaturgical approach}

The analogy of the court hearing as theater is based on Erving Goffman's understanding of "the theatrical frame" (Goffman, 1974) and his recognition of the "presentation of self" as part of a performance (Goffman, 1959). The performance serves to influence other participants and the audience in order to control their impressions of the performers and the situation (Goffman, 1959). In The presentation of self in everyday life, Goffman (1959, p. 85) also introduces the term "'performance team', or in short, "team" which refers to how performers co-operate during the social interaction (Goffman, 1959). The performance within teams is strategic and based on trust and on a common definition of the situation (Goffman, 1959). In the criminal court, the spatial positioning clarifies who belongs to each team, for instance the defense lawyer sits next to the client (see Flower, 2018b, p. 58).

In the situation of a criminal trial, the performers try to sustain a particular definition of the situation, which traditionally involves the defendant's claim of innocence and the prosecutor's claim of guilt (Flower, 2018b, p. 45). Despite this disagreement, the prosecutor's team and the defense team, together with the judges, work "towards sustaining the "working consensus"” (Flower, 2018b, p. 55, see also Goffman, 1959, p. 97). In any social interaction, there will also be disruptions of the teams' performance, of their presentation of the definition of the situation, which may mean that "the interaction may come to a confused and embarrassed halt" (Goffman, 1959, p. 
23). A criminal trial involves inherent conflicts that challenge the working consensus in the court. For instance, in order for the defense to maintain their definition of the situation, they may display antagonism towards the prosecutor's definition of the situation. This theoretical perspective provides the lens through which to analyze the interactions and in court, between the 'teams'; the defense, the prosecutors, the judges, and the company Telia. As such, it helps to distinguish both appearances and arguments in court, in order for us to understand the various expressions of unbelonging employed by the defense.

\section{Methods: court ethnography}

This paper presents an ethnographic study of the theatrical performance in the courtroom in which the performance of the defense lies at the center of the analysis. We conducted the observations between September $5^{\text {th }}$ and December $19^{\text {th }}, 2018$, during the Telia trial at Stockholm District Court. The original aim of the observations was to study the corporation's and defendants' legal defense, with the verbal speech acts constituting the central focus of the analysis. During the observations, we became aware of, and took notes on, the many other aspects of the trial, and developed an interest in the trial's dramaturgical aspects. In other words, the analytical frame of this paper, the dramaturgical approach, emerged as an alternative theoretical lens during the trial and was not part of the original idea of the courtroom ethnography. Although our original theoretical approach, which was focused on accounts and the defense mechanisms employed at trial, and which we have applied in previous publications (see Schoultz \& Flyghed, 2021), contains similarities with "presentation of self" (see Törnqvist, 2017), this article has another point of departure, since it focuses on not just the defense performance, but on the social interactions in court between the defense, the prosecutors and the judges. However, since the original aim of the observations was to understand the defendants' accounts, the field notes are largely lacking detailed descriptions of the surroundings and gestures. This is a limitation in the empirical material. However, the analysis aligns with the analytical tradition in court ethnography of focusing on "what people say in courtrooms, how they are saying it, and how they construct reality through linguistic utterances" (Bens, 2018, p. 336).

During the trial, we were primarily present during the prosecutor's presentation of the charges, the opening presentations of the prosecution and the defense cases, the presentation of the defense case for each point in the indictment, the cross examination of the defendants and the prosecutor's and lawyers' closing arguments. In addition, the trial comprised several weeks of witness testimony, which we have only observed on a small number of occasions. In total we made observations on 20 days of the court hearing. During the trial we made detailed field notes of what was said in court and also of the way the different actors acted in the courtroom. Our observation from the open gallery at the back of the courtroom created a distance to the court actors and allowed for the extensive writing of field notes in real-time on a laptop. Since we also taped the hearings 
in court, we were able to then write out the field notes cleanly and include full quotes, as well as adding details from memory that were not "talk", thus producing so-called full or complete field notes (Emerson et al., 2011). A day in court usually generated approximately 10 pages of field notes.

Before the trial, we asked the court administrator whether we would be allowed to audiotape the hearing, which we were as long as this did not disturb the proceedings. Since the courtroom is a public place, it is not considered necessary to ask the participants for consent (Flower, 2018b, p. 90). Given this, and since this particular trial was a public occurrence in itself, we decided not to ask the involved actors for consent. After some time, when we were more or less the only spectators, we were questioned in the waiting area during the breaks by the defense lawyers and later on by the prosecutors about who we were, and we then took the opportunity to present our research.

In addition to the observations, we have conducted interviews with two of the defense teams and the presiding judge. The interviews were conducted less than a week after the judgement was handed down in February 2019. We also approached the third defense team and the prosecutors for interviews, but without result. All three interviews were conducted at the workplaces of the defense lawyers and the judge and lasted about 1-1.5 h. The three interviews were audiotaped and later transcribed.

The coding and analysis of all the empirical material has been approached by means of frame analysis, that is, an analysis of how the phenomenon in question is framed. Goffman (1974, p. 127) developed the frame concept in his ground-breaking work Frame analysis, in which he stated that "the first issue is not interaction but frame". Since Goffman published his book, the concept has been used and elaborated in many different contexts (Bacchi, 1999; Benford \& Snow, 2000; Entman, 1993; Reese, 2007). According to Entman (1993, p. 53), framing essentially involves selection and salience, where salience is defined as "making a piece of information more noticeable, meaningful, or memorable to audiences". During the Telia trial, we have observed how different teams, in their performance in court, frame the trial in order to sustain their definition of the situation. Thus, the analysis of framings is coupled with the dramaturgical approach in order to understand the performances of unbelonging in court.

We conducted the analysis by reading both the field notes and the interview transcripts several times and then manually coding interactions between actors in the court, i.e., between the defense and the prosecutor, between the judge and the prosecutor and between the prosecuted individuals and the company. In these coded interactions, we paid particular attention to the different actors' framings and definitions of the situation. During this phase, the theme of 'performing unbelonging in court' emerged in the material and it developed into a central node of analysis. Obviously, the observations and interviews also contain several other central themes, such as the expression of emotions and the use of neutralization techniques. In this paper, these themes are only expounded to a limited extent or not at all, since our principal aim has been to elaborate on 'the performance of unbelonging in court'. 


\section{The theater of the telia trial}

\section{The court setting and the criminal case}

On September 5th, 2018, the first day of the hearings at the Stockholm District Court, the waiting room was crowded. All major TV-channels and newspapers in Sweden were present. The court hearing was not just public and well-attended; there was something about the accused that made the first day of the court hearing somewhat special. One of the journalists wrote after the first day: "Well-dressed middleaged men, in contexts such as this it is difficult to distinguish lawyers from suspected criminals" (Cantwell, 2018). But on a closer look, this observation was not entirely accurate; two of the defendants were more casually dressed than their lawyers, one of them in sneakers. However, men of this kind are not generally portrayed in court as defendants in a criminal trial, and this is one of the reasons why the case is an interesting object for an analysis of performances in court, and in particular 'unbelonging in court'.

When we entered the courtroom on the first day and found seats in the open gallery at the back, we could see in front of us, on a slightly elevated stage, the two professional judges (one of them acting as the chair of the court), the four lay judges, who represent the general public, and the clerk, already seated. ${ }^{3}$ On the right-hand side from the perspective of the open gallery at the rear of the courtroom, the two prosecutors found their places. On the opposite side from the prosecutors, one of the defendants was seated with his defense team. The other two defendants, the former CEO, and his defense team, were placed opposite the judge with their backs to the open gallery. Behind this defense team, there were tables and chairs assigned to representatives of Telia. In the first week, the corporation was represented by the company's chief lawyer and a corporate lawyer, and also two defense lawyers. However later on in the trial, the corporation was on most days represented by only one defense lawyer. In addition, two translators were present in court since two of the defendants were native Finns.

The courtroom consisted of three main teams: the prosecutors, the accused individuals' defense teams, and the judges. The Telia company's defense team had a somewhat different role, to which we will return. The three teams had clearly defined roles, which are fundamentally different (see Flower, 2018b, p. 45). The prosecutor's role is to show that the indictment is well founded and that it should result in a guilty finding. The defense lawyers' role is to advance their clients' interests and cast doubt upon the prosecution's statements and evidence. The role of the third team, the court, led by the presiding judge, is generally more passive and involves determining whether the arguments presented should lead to a finding of guilty or

\footnotetext{
3 The verdict in a criminal case in a Swedish district court is usually determined by one professional judge and three lay judges. If the trial is expected to be extensive and to take a long time, an extra professional and an extra lay judge will be added as back-ups. These are present during the entire trial, but only act as substitutes if one of the lay judges or the professional judge needs to step down, e.g. for reasons of illness.
} 
not guilty. This role also involves being the audience for the performances of the prosecution and defense teams, as they attempt to control impressions of the situation (see Goffman, 1959, pp. 26f, 97). As we will see later on in the analysis, in this particular case the judge took quite an active role in correcting the performances of the other teams when they were not acceptable.

There is also another audience, the spectators in the courtroom. On various occasions journalists, relatives and others, such as school classes, were present and listened for part of the day. Media representatives have a special role as an audience, since they open the courtroom to the public whose picture of the play is mediated through the media (Walenta, 2020).

On the first day of the court hearing, the professional judge gave the floor to the prosecutors to present their claims. The two prosecutors opened their 555 slide PowerPoint presentation and started to present the charges (their statement of facts). ${ }^{4}$ One of their overall arguments was that "Gulnara Karimova [the daughter of the President of Uzbekistan at the time] was in control of the telecom market in Uzbekistan and that her position had been known to the telecom companies." The prosecutor maintained that Gulnara Karimova had been the formal owner of Takilant, the offshore company to which Telia had paid money for licenses. The two prosecutors' opening presentation lasted until after lunch on the second day. The first presentation by the prosecutors was significant for the trial in several ways. First, it was a trial about a "paper trail"; the main part of the evidence (from both sides) consisted of documents, often e-mails, which were copy-pasted into PowerPoint presentations. Second, the fact that the prosecuted events took place over 4 years (2007-2010) resulted in lengthy presentations. Third, the lack of consistency and structure in the prosecutors' presentations, or performances to use Goffman's terminology, gave us the impression of uncertainty. In the field notes, we find recurrent observations of the prosecutors' apologies for speech errors, and notes on their hesitations and on the lack of precision in their presentation. The prosecutors' difficulties in presenting the complex case were a constant source of disruption in the social interactions in court; they were used by the defense teams to their advantage and also resulted in critical questions and reprimands from the presiding judge.

In the following, we will analyze the 'performance of unbelonging in court' by the defendants. The analysis includes both how the defendants carried themselves and how they expressed themselves frontstage and backstage. The performance of 'unbelonging in court' also includes the defense claim of being scapegoated by the company, as well as their framing of the complexity of the case and of the prosecution as unjust, in relation to which they directed accusations against the prosecutor. In order to understand the central legal battle, we will first examine the defense's expression of the defendants' unbelonging in court in relation to the crime under prosecution.

\footnotetext{
4 Two of the main principles governing trial proceedings in Sweden are those of orality and immediacy. These imply that the evidence should be presented orally; the parties should, in general, talk freely; and the judgement should be based on the facts and evidence presented before the court.
} 


\section{It is not a crime and the defendants do not belong in Court}

The three teams of defense lawyers representing the prosecuted individuals comprised what could be described as some of Sweden's top lawyers in the field of white-collar crime. They formally represented only their respective clients, but during the court proceedings it emerged that the three teams had built their defenses in line with one another. In Goffman's (1959, p. 94) terms the teams appeared as a "united front" and collaborated in order to maintain the same "definition of the situation before the audience" (Goffman, 1959, p. 88). The shared definition of the situation was that the events did not constitute a crime and that none of the accused individuals should have been in court having to defend themselves. The united front and "collegial solidarity" (Goffman, 1959, p. 159) was also evident in the backstage area, where the three defense teams stood together in the breaks, drinking their coffee and chatting. The collegial backstage activity between the prosecuted individuals' defense teams was also discussed in the interviews, with one of the defense lawyers explaining that "We shared the same interests." Their shared interest was based on the defense strategy, which was firstly to maintain that the events did not break any law, and secondly that if the court decided that the law had been broken, that their clients had lacked any intent. The defense teams' framing of a lack of any intention to commit a crime, framing the accused as having made no personal gain from the affair, ties into a common form of accounts used in organizational crime (see Box, 1983). In other words, the defense teams' united performance in the courtroom served to reinforce the defendants' unbelonging in court.

The main legal battle in court related to the position of Gulnara Karimova. The Swedish law on bribery at that time required there to be a connection between the improper benefit received and the performance of the recipient's work or duties, which could entail a risk for undue influence. The defense continuously brought up, that Gulnara Karimova was not a bribable subject according to Swedish law at the time - this being because she had not been acting in the context of official duties as a state employee or as a contractor in a position of trust performing a function within the telecom sector, but rather in the capacity of a businesswoman. One of the defense attorneys expressed this ambiguity in the following way during the closing arguments: "When we heard the suspicions, a thought arose in me as a lawyer. This is not a bribery offense that the prosecutor is describing, it might be anything at all, but it is not a bribery offense" (Defense lawyer, day 42). The defense teams' framing ties into a well-known rhetoric from white-collar crime cases about the ambiguity of the nature of the alleged crime, and whether the acts in fact constitute crimes at all (see Croall, 1993; Mann, 1988, pp. 114-115), The defense lawyer argued that the prosecuted acts did not fall within the remit of the legislation that was in place at the time. The defense went so far in their argumentation as to indicate that the acts might possibly fall within the current legislation, which includes what is called 'trading in influence'. However, the overall argumentation from the defense was that this was not a crime and that the defendants did not belong in court. In the following, we will present how the defendants embodied unbelonging, through an indirect expression of status and standing, both frontstage and backstage. 


\section{The defendants' embodied unbelonging in court}

During the whole trial, the defense would frame the decision to prosecute the defendants as wrong. Simultaneously, the defendants performed, both frontstage in court and backstage in the waiting area, that they did not belong there, although the three defendants' 'performance of unbelonging in court' was expressed differently. One of the defendants showed his unbelonging through an obvious unease in combination with politeness. For example, he explicitly expressed in the courtroom at the start of the trial that he was nervous. He also stressed that the entire setting was new to him; he had never been in a court before. During the breaks in the waiting area, we observed how his own, but also the other's defendants', lawyers supported him with encouraging comments. He always acted politely in relation to the prosecutor, often by referring to him as Mr. Prosecutor, which is not customary for defendants in a Swedish court. In addition, during cross-examination he expressed without any irony in his voice, for example, that he was very happy to answer the prosecutors' questions, and afterwards he shook the hands of both prosecutors. In this way, he performed an unbelonging in the court through his polite and accommodating manner, and by indicating that he did not belong in this environment.

In contrast, the former CEO, was almost arrogant in his performance. His answers to questions from the prosecutor were often brief, there was a tone of irritation in his voice over the questions asked, and he sometimes started his answer with a loud sigh. While the other two defense teams alternated in sitting on the seats opposite the prosecutor when it was their turn to present or to conduct cross-examination, the defense team of the former CEO remained, by choice, in the seats opposite the judges throughout the entire trial, with the exception of cross-examination. When asked about this in our interview with the defense lawyers, they stated: "We did not think that he actually belonged among the accused" (Interview defense lawyers). This is also what the defendant himself expressed through his behavior during the court hearing, acting as if he did not belong there. After the final cross-examination by the prosecutor, he stood up and was about to walk away, when one of his own lawyers said: "Wait, I might have questions for you". The defendants stopped and said, "No you don't", and then walked back to the seat beside his lawyers, as though he was in control of the trial. His performance was met by collective laughter in the court, but he did not smile himself.

The third defendant instead signaled belonging among the professionals in court, rather than among the accused. He was always well dressed in a suit and could easily have been mistaken for a lawyer. In fact, this defendant was observed joining his lawyers as they entered the court, bypassing the security check that everyone except police, prosecutors and defense lawyers had to pass through before entering the building. In this sense, the journalist's remark mentioned above, that the accused could not be separated from the defense lawyers, was quite accurate, at least in relation to one of the defendants. The same defendant always performed with great confidence in court, taking the opportunity to direct criticism at the investigation and, as we will exemplify below, directing accusations at both the prosecutor and the corporation. Although the three defendants had different expressions, they did in their own way mark their social status and performed what we understand as a form of 
unbelonging in court, in the way they dressed, the way they moved and the way they talked. The defendants' performance was linked to the defense teams' united front against the prosecution, an adversarial performance that we will elaborate on. First, however, we will discuss how the framing of the relationship between the corporation and the defendants, as well as the framing of the complexity of the case, were used in the performance of unbelonging in court.

\section{The defendants' claim of being scapegoated}

When analyzing the interactional aspects of the trial, another aspect became apparent that we also interpret as a performance of unbelonging in court, namely that the three executives claimed that they were being scapegoated by the company. The role played by the defense team representing Telia was quite different from that of the defense teams representing the executives, and involved a limited court performance. The passive role of the corporate defense team became apparent when reading through the field notes from the court hearings. The representatives of Telia were rarely mentioned, but when they were, the notes were mostly focused on their absence and passivity. In contrast to the other defense teams, the company's defense team did not question the prosecutors' definition of the situation. On the first day of the trial, when all parties to the case presented their positions, Telia's lawyer asked himself "Does it constitute a crime? The Telia Company has no opinion on this. We leave that to the court to determine." Their lack of defense is quite natural given that the company had nothing to lose during the trial, if the individuals placed on trial were convicted of criminal offenses, besides the confiscation of profits. And since the Dutch authorities would confiscate this amount anyway in the case of the defendants being acquitted, the company was not at risk of having to make any additional payments. Further, the company was required to keep to the acknowledgement of guilt that had already been made in the American courts, in order to avoid breaking the agreement reached with the American authorities. Thus, the company did not enter into an argumentative role in relation to the executives and their defense teams. On the other hand, there was no sign of the collegial solidarity that was observed between the other defense teams. Instead, the other defense teams argued continuously during the trial that the defendants had been scapegoated by the corporation. Scapegoating involves the corporation transferring the responsibility for an act or event from the corporation itself to one or a few symbolic figures. It reduces complexity and allows a corporation to avoid scrutiny (Bachmann et al., 2015). This is also what the defense then argued in court when they referred to the global settlement: "Telia has had powerful commercial reasons for entering into this contract and it should not be ascribed any evidentiary value. The incentive, we have already said, was 1.4 billion [Swedish Kronor]". During the trial, the defense argued that the only reason for Telia's confession of being guilty of bribery offenses as part of the global settlement was commercial, and that this had no bearing whatsoever on the question of the guilt of the executives.

In the closing arguments on the final day, one of the defendants, the third of those referred to above, described the company's behavior as "cowardly" and 
"backstabbing". He continued reading from a manuscript and in a toneless voice described how the defendants had been scapegoated by the company: "The company decided to throw three individuals under the bus in order to receive hundreds of millions of dollars in reduced costs". While the scapegoating shifted the blame from the corporation to a few individuals (Bachmann et al., 2015, p. 1129), the process of blaming a few selected individuals also constitutes part of the logic of these criminal proceedings. It is difficult to imagine a court hearing in which everyone involved in the decision-making process and implementation of a business deal like Telia's in Uzbekistan could be prosecuted (see Jordanoska, 2017 on presenting manageble cases). During the trial the company lawyer's defense counsel repeatedly referred to a long list of people who had been involved in the business deals. When the defense argued during the trial that the defendants were not being prosecuted because they were the individuals who bore the most guilt, but rather because they were the most practical/convenient scapegoats, they were illustrating the complexity of corporate crime. Corporate structures create unique opportunities for the framing of a diffusion of responsibility, since these structures make it difficult to determine who is to blame (Croall, 1993). Here, the framing of the defendants as being scapegoated by the company enhances the argument that these three executives do not belong in court; they do not deserve to take the fall for organizational practices. The claim of being scapegoated also ties into the framing of the complexity of the case, which will be discussed below in relation to the particular crime under investigation.

\section{Framing the complexity of the case}

During the court hearing, the different teams seemed to have a common understanding of the complexity of the case. However, the defense teams on the one hand, and the prosecution team on the other, framed the complexity of the case in different ways in order to sustain their definition of the situation. When the prosecutors were criticized by the judge or the defense for being unclear in their presentation, they often excused themselves by referring to the complexity of the case. This ties into an understanding that investigations against corporations are complicated and difficult, and thus difficult to prosecute (Croall, 1993; Beare, 2018). In the current case, however, the complexity argument was mostly used by the defense teams as a means of framing themselves as having a disadvantageous position in relation to the prosecutor and the ambiguity of the case, and contributed to the performance of unbelonging in court. As early as the first day, our notes included the following reflections: "Over the course of the day, the defense lawyers return to the fact that the investigation documentation is 38,000 pages long, and that there is an information deficit, or an evidence deficit, for the defense in relation to the prosecutors". This argument continued throughout the trial. In addition, thousands of pages of material and e-mails are significative of white-collar crime cases (Burns \& Meitl, 2020; Jordanoska, 2017). The framing of the case as complex, and a focus on the immense scope of the material in the case, was repeatedly presented as a criticism of the prosecutors' investigation. However, the complexity of the case was not only related to the size of 
the investigation, but also to the bribery legislation (who constitutes a bribable subject), the fact that the events under prosecution took place over several years and involved a large number of individuals, and also the role played by the parallel international investigations and settlements. The following example shows how one of the defense lawyers brought up the complexity issue again during closing arguments, formulating the defense's criticism of the trial in a calm and confident voice:

A huge trial, but we have not scratched into the tip of the iceberg but rather only the surface of the tip of the iceberg. There is very little in this investigation that is being put on the table in court. And a great deal that has not been investigated at all. [...] The lack of central information, personal interests in the information provided, personal interests in the deals that have been struck, that is to say, a minefield of uncertainties. (Defense lawyer, Day 41).

The defense teams' framing of the case can be interpreted as a form of performance of unbelonging in court, since the complexity argument opens up for doubt as to whether anyone could be held to account when the circumstances are not clear. Similarly, the same defense lawyer expressed the ambiguity issue from the perspective of his client. At the beginning of the final day, the defense lawyer opened his closing arguments with a manuscript in front of him, and with a dramatic voice portrayed how the investigation started for his client:

“That's when [the client's] nightmare started, which will soon have been going on for 6.5 years. When we heard what the charges were about, it was a despairing [client's name] who tried to explain that he hadn't done anything wrong. He, a bank lawyer, not of medium rank, perhaps, but at a very modest level, who worked on the service line, he was not on a decisionmaking line. He does things that corporate lawyers do, ensures that decisions that are made by those running the business are correct, compliant with laws and regulations. That he was then accused of what came to be called Sweden's biggest corruption scandal." (Defense lawyer, day 42).

The defense lawyer's framing here linked into the complexity of corporate structures when it comes to determining who is to blame. The lawyer was arguing that it was unfair that his client, given his "modest" position within the company, should be blamed for the biggest corruption scandal in Sweden. The lawyer was indicating that his client didn't belong there; if anyone did, it was the company. The defense framing of corporate structure, and the questioning of whether the accused were the right ones to be held to account, constitutes yet another example of the performance of unbelonging in court. The adversarial relation described here between the former executives and the corporation is related to the specific character of the crime under prosecution. In this trial, there was also another adversarial relationship between the defenses and the prosecutors when arguing that the prosecution is unjust, which will be analyzed below. 


\section{An unjust prosecution}

In contrast to many other social interactions, there is an embedded "adversariality" in the drama of a criminal court hearing, namely that between the prosecution and the defense. Flower describes the Swedish legal culture as being "less adversarial" and "less combative than other systems" (Flower, 2018a, p. 227). However, compared to Jordanoska's (2017) description of the culture of cooperation between the prosecution and defense teams in order to aid the efficiency of complex fraud trials, the interactions between the defense and the prosecution in the Telia trial had a strong adversarial character. This may well have to do with the pursuit of individual accountability for corporate misconduct spurring a higher degree of adversarialism (Jordanoska, 2021). The defense's framing of the prosecution as unjust includes elements of action and interaction that we interpret as another aspect of the performance of unbelonging on court.

During the trial, the defense teams framed the accused as having already been convicted in the "media trial" (cf. Åkerström et al., 2016), portraying the prosecutor, who had been giving interviews during the preliminary investigation phase, as being responsible for this. During the defenses' statements of facts, one of the lawyers from the former CEO's defense team stated that: "he has stood as a suspect for more than four years. The pressure from the mass media has been very intense and the prosecution have been good at exploiting the media's interest in their statements that Telia and its employees have bribed their way to becoming established in Uzbekistan." (Defense lawyer, day 3). The three defense teams, and the accused themselves, maintained a joint front and performed a form of "dramaturgical loyalty" (Goffman, 1959, p. 207) throughout the trial. They jointly framed the prosecution as inconsistent, wrong and unjust and as in itself being a punishment for the accused. When all the evidence had been presented and all the hearings had been held, the court reviewed the personal circumstances of the suspects (Personalia, and the defense described the consequences of the prosecution and how the defendants had suffered both financially and privately. One of the defendants explained that he was now divorced as a result of the criminal process, and that he was supporting his children financially although he had "lost his job on two occasions; first as a result of the criminal investigation, and then when the prosecution was brought" (Defendant, Day 39). This is in line with what other scholars have observed in white-collar crime cases, where references are made to the suffering, in personal and professional life, already experienced by the defendants during the criminal justice process, with the defendants thus framing themselves as the victims (Mann, 1988; Goldstraw-White, 2011; Levi, 1991, 2006). The defendants' framings also tie into a gendered narrative of the good father and breadwinner (Gathings et al., 2013).

On the last day, one of the defendants took the opportunity to presenthis own view of the prosecution and the effects it had had on him after his defense lawyer's closing arguments. It was a well-prepared speech, and as (Goffman, 1959, p. 42) notes, a well-prepared presentation of self may involve following a predesigned script. The speech began by raising questions about the two prosecutors: 
I must express my concerns regarding the prosecutors' behavior and actions in handling the case. They have tried to cover a very one-sided view of my actions, cherry-picking e-mails without showing the whole transparent correspondence, they tried to hold back substances of material, or deliver such materials at a very late stage during the process. They have drawn conclusions by cutting corners without evidence, purely based on fantasies and conspiracies. (Defendant, Day 42)

The speech is another example of the 'performance of unbelonging in court', with the defendant brimming with confidence and acting as though he were the accuser and not the accused. By acting as the one who has the right to make condemnations, the defendant enhances the impression of himself as being wrongfully placed among the defendants in a criminal trial. In what may be interpreted as the defendant attempting to defend his name and save face (see Goffman, 1959, p. 238; Akerström et al., 2016), by directing accusations against the prosecutor, he also created what Goffman has described as "a scene" that "destroy[s] or seriously threaten[s] the polite appearance of consensus" (Goffman, 1959, p. 205). The presiding judge did not approve of the defendant's adversarial performance against the prosecutors and interrupted the defendant's speech, saying in a clear and annoyed voice:

I must stop this; I am sorry. We cannot allow someone to sit and direct accusations against the prosecutor before a sitting court in this way. If you are going to say something, then you will have to be objective. I feel that you crossed a line here. I can understand that you feel that way, but we have to maintain a good and objective tone. I will not allow this! (Presiding judge, day 42)

The last words were uttered with emphasis in a very determined voice. The judge's interruption of the defendant clearly signaled that the performance constituted a breach of the emotional regime of the criminal trial (see Flower, 2018b, p. 217), whereby the court is viewed as objective, fair and respectful to those who are party to a trial, by intentionally threatening the face of the prosecutors (see also Törnqvist, 2017, p. 317). The way this was played out in the court manifests many similarities with (Goffman, 1959, p. 227) description of how an audience, in this case the presiding judge, gives the performer a hint, as a warning, that "his show is unacceptable and he better modify it quickly if the situation is to be saved". In Goffman (1959, p. 222) terms, the judge's hint may be understood as a protective practice "in order to help the performers save their own show". In this case, the defendant did modify his performance by skipping the parts of his original script that were directed at the prosecutors. Having given a long speech on his innocence and on the claim of being scapegoated by the company (analyzed above), however, he continued his criticism of the prosecutors. He was quickly interrupted by the presiding judge, who showed obvious irritation and in a brusque, instructional tone, told the defendant to stop. The judge's interruption of the performance of the defendant had now moved away from the "subtleness" that is representative of Swedish court culture (cf. Flower, 2018b), and constituted a clear sanctioning of the performance. The defendant's criticism of the prosecutors was not essentially different from the closing arguments that had just been presented by his defense lawyers, with statements 
such as "there are serious flaws in the prosecutor's conclusions" [...] "The interpretations are often sweeping, unclear and lump groups of people together" [...] "contain many things that are simply incorrect." [...] "[It] has been difficult for our client to free himself of the idea that this has been deliberate." (Defense lawyer, Day 42).

These statements did not result in any corrective action from the judge. In contrast to the defendant, the defense lawyers managed to perform the "appropriate adversarialism" that is representative for Swedish court culture (Flower, 2018b, p. 225). However, the framing is the same, the prosecution is flawed and unfair and thus the defendant does not belong in court. At the end of the day, one of the defense lawyers apologized to the court for not informing the defendant of "how you are permitted to speak in court" (day 42). The defense lawyer's apology here manifests what (Flower, 2018b, p. 126) has described as the defense lawyer's responsibility of ensuring that "clients stay in face" and show a "good courtroom manner". Hence, the 'performance of unbelonging in court' seems to have limitations; direct accusations against the prosecutor are not accepted by the sitting judge.

\section{Concluding Discussion}

This paper contributes to the tradition of 'court ethnography', but from the perspective of a less traditional form of crime. What is significant here is the type of case being prosecuted, a high-profile transnational corporate bribery case. As others have noted (Pontell \& Geis, 2007), courtroom ethnographies of white-collar crime cases are rare. Therefore, this paper provides a unique insight into the dramaturgical aspects of a court proceeding involving a multinational corporation and three former executives. Thus, by advancing the tradition of court ethnography, and the theoretical understanding of the court as a theater, to include the case of corporate crime, the paper contributes with an understanding of the performance of unbelonging in court. Throughout the analysis, we have demonstrated how unbelonging is performed, partly by the defendants' performances and partly by the defense teams' framing of the case, including their framing of the defendants as having been scapegoated by the corporation and of the prosecution as being unfair and illegitimate. The defense teams' "definition of the situation" (Goffman, 1959, p. 88), that the defendants did not belong in the court setting in the role of suspected criminals, might also have been analyzed from the perspective of accounts (see Scott et al., 1968). The ways in which white-collar criminals neutralize their behaviour is quite well documented (see for example Benson, 1985; Goldstraw-White, 2011; Klenowski \& Copes, 2013; Schoultz \& Flyghed, 2019), but this study may contribute with a new dimension via an understanding of the way performances in courts contribute to face saving (see Goffman, 1959, p. 238) among white-collar defendants.

Given the social standing of suspected white-collar criminals, these forms of performance might be unique to this particular trial but may also be prevalent in similar cases in which businessmen, or other professionals, are under prosecution. The defendants' demeanor bears some resemblance to Beare's (2018) description of 'entitled ease' among the powerful segments of society involved in corruption. On the other hand, the defendants in the Telia trial do not to the same extent belong to 
powerful elites as those in Beare's (2018) examples, not least since the former Telia executives who were on trial lacked any backing from the corporation. Instead, our arguments about their performance of unbelonging in court are based on their relatively high social status and standing in relation to other defendants in court. The journalist's remark from the first day of the trial, about the similarities between the lawyers and the defendants, relates not only to (un)belonging in terms of the defendants' clothing, but also to their performed identity. The way the defendants carried themselves and interacted with others, both frontstage and backstage, indicated that these were not ordinary criminal suspects. This begs the question of whether the performance of unbelonging in court is unique to white-collar crime defendants. Other have shown that defendants' identities are constructed and negotiated in the courtroom, and that this includes narratives of a nondeviant identity (Gathings et al., 2013). It is thus perhaps not a matter of whether defendants in general may perform unbelonging in court, but rather one of howthe social standing of suspected white-collar criminals shapes the way in which they perform unbelonging. The complexity of white-collar and corporate crimes in general (Croall, 1993; Beare, 2018), and this case in particular, allows for certain expressions of unbelonging. The ambiguity of the suspected crime provided the defense with a basis for arguing that the act was not a crime at all (see Croall, 1993; Mann, 1988), pp. 114-115) and that the defendants should not have ended up in court. Perhaps the fact that there was no injured party present allowed the defendants to be framed as the ones who had been victimized, by the corporation and the 'media trial'. The three defense teams' adversarial performance in relation to the prosecutors must then be understood as an expression of their performed conviction regarding the defendants' unbelonging in court. The presiding judge, in trying to control the working consensus of the court, set limits for the extent to which the defendants were allowed to express their unbelonging; unreasonable criticism against the prosecution case was not acceptable. In addition, the defense teams' adversarial performance in relation to the Telia corporation can only be understood on the basis of the type of crime under prosecution. What is significant is the relationship between the large corporation and the three prosecuted individuals. They were not accused of committing crimes against the company, but for the company, and they perceived that they were being scapegoated and sacrificed in order to allow the company to continue doing business. The complexity and ambiguity of a transnational corporate bribery case permeated both the interactions during the trial and court's judgement. During the press conference at which the presiding judge announced the acquittal of the three defendants, the judge began by saying, "This is a complex case; the legislation is difficult" (Press conference, February 15, 2019). As several of those involved pointed out during the trial, the case is unique, at least in the Swedish context. The observed performances of unbelonging in court are embedded in the particular circumstances of this trial, the corporation versus its former executives, the complicated transnational corporate bribery offense and the outspoken prosecutor, who had been serving the media with his interpretation before the trial began. Thus, the knowledge we can draw from this court ethnography is not necessarily transferable to other crime types or legal cultures. However, we believe the analysis is nonetheless relevant beyond this particular case, as has been discussed above. It provides an example of how interactions in 
court include constructions and negotiations of belonging and unbelonging in court, which create an opportunity for comparisons with other types of cases in other contexts.

Acknowledgements The authors would like to thank Nina Törnqvist at the Department of Sociology at Uppsala University, whose comments and suggestions have improved the article significantly. The authors are also grateful for the valuable comments provided by the anonymous reviewers.

Funding Open access funding provided by Lund University. This work was supported by the Swedish Riksbankens Jubileumsfond (RJ P15-0176:1) and Torsten Söderbergs foundation (project R17/19).

\section{Declarations}

Conflict of interest The authors declare that they have no conflict of interest.

Open Access This article is licensed under a Creative Commons Attribution 4.0 International License, which permits use, sharing, adaptation, distribution and reproduction in any medium or format, as long as you give appropriate credit to the original author(s) and the source, provide a link to the Creative Commons licence, and indicate if changes were made. The images or other third party material in this article are included in the article's Creative Commons licence, unless indicated otherwise in a credit line to the material. If material is not included in the article's Creative Commons licence and your intended use is not permitted by statutory regulation or exceeds the permitted use, you will need to obtain permission directly from the copyright holder. To view a copy of this licence, visit http://creativecommons.org/licen ses/by/4.0/.

\section{References}

Askinosie, M. S. (1989). Cool hand lawyers: White collar crime and tactics of the prosecution and defense comment. Journal of Dispute Resolution, 1989(7), 107-138.

Bacchi, C. (1999). Women, policy and politics: The construction of policy problems. SAGE.

Bachmann, R., Gillespie, N., \& Priem, R. (2015). Repairing trust in organizations and institutions: Toward a conceptual framework. Organization Studies, 36(9), 1123-1142.

Barrett, C. J. (2013). Courting Kids: Inside an Experimental Youth Court. New York University Press.

Beare, M. E. (2018). Entitled ease: Social milieu of corporate criminals. Critical Criminology, 26(4), 509-526.

Benford, R. D., \& Snow, D. A. (2000). Framing processes and social movements: An overview and assessment. Annual Review of Sociology, 26(1), 611.

Bens, J. (2018). The courtroom as an affective arrangement: Analysing atmospheres in courtroom ethnography. The Journal of Legal Pluralism and Unofficial Law, 50(3), 336-355.

Benson, M. L. (1985). Denying the guilty mind: Accounting for involvement in a white-collar crime. Criminology, 23(4), 583-607.

Bergman Blix, S., \& Wettergren, А. (2018). Professional emotions in court: A sociological perspective. Routledge.

Box, S. (1983). Power, crime and mystification. Sage.

Burns, R. G., \& Meitl, M. B. (2020). Prosecution, defense, and sentencing of white-collar crime. In M. L. Rorie (Ed.), The handbook of white-collar crime (pp. 279-296). Wiley.

Cantwell, O. (2018). Ingen enkel resa att få Telia-cheferna fällda för mutbrott, 4 September 2018. Aftonbladet.

Croall, H. (1993). Business offenders in the criminal justice process. Crime, Law and Social Change, 20(4), 359-372.

Emerson, R. M. (2008). Judging delinquents: Context and process in juvenile court. Aldine transaction.

Emerson, R. M., Fretz, R. I., \& Shaw, L. L. (2011). Writing ethnographic fieldnotes. University of Chicago Press.

Entman, R. M. (1993). Framing: Toward clarification of a fractured paradigm. Journal of Communication, 43(4), 51-58. 
Flower, L. (2018a). Doing loyalty: Defense lawyers' subtle dramas in the courtroom. Journal of Contemporary Ethnography, 47(2), 226-254.

Flower, L. (2018b). Loyalty work: Emotional interactions of defence lawyers in swedish courtrooms. Doctoral Thesis. Lund University

Gathings, M. J., \& Parrotta, K. (2013). The use of gendered narratives in the courtroom: Constructing an identity worthy of leniency. Journal of Contemporary Ethnography, 42(6), 668-689.

Goffman, E. (1959). The presentation of self in everyday life. Penguin Books.

Goffman, E. (1974). Frame analysis: An essay on the organization of experience. Harvard University Press.

Goldstraw-White, J. (2011). White-collar crime: Accounts of offending behaviour. Palgrave Macmillan.

Jordanoska, A. (2017). Case management in complex fraud trials: Actors and strategies in achieving procedural efficiency. International Journal of Law in Context, 13(3), 336-355.

Jordanoska, A. (2021). Regulatory enforcement against organizational insiders: Interactions in the pursuit of individual accountability. Regulation \& Governance, 15(2), 298-316.

Klenowski, P. M., \& Copes, H. (2013). Looking back at Other People's Money: A qualitative test of Cressey's classic hypothesis of trust violating behavior. Journal of Qualitative Criminal Justice and Criminology, 1(1), 29-52.

Kupchik, A. (2006). Judging juveniles: Prosecuting adolescents in adult and juvenile courts. New York University Press.

Levi, M. (1991). Sentencing White-Collar Crime in the Dark?: Reflections on the Guinness Four 30(4), 257-279.

Levi, M. (2006). The media construction of financial white-collar crimes. The British Journal of Criminology, 46(6), 1037-1057.

Levi, M., \& Lord, N. (2017). White-collar and corporate crimes. In A. Liebling, S. Maruna, \& L. McAra (Eds.), Oxford Handbook of Criminology (6th ed). Oxford University Press.

Lord, N., \& Levi, M. (2016). Organizing the finances for and the finances from transnational corporate bribery. European Journal of Criminology, 14(3), 365-389.

Mann, K. (1988). Defending white-collar crime: A portrait of attorneys at work. Yale University Press.

Paik, L., \& Harris, A. (2015). Court ethnographies In H. Copes \& J. M. Miller (Eds.), The Routledge handbook of qualitative criminology (pp. 283-295). Routledge.

Pontell, H. N., \& Geis, G. L. (2007). Preface. In H. N. Pontell \& G. L. Geis (Eds.), International handbook of white-collar and corporate crime (pp. xi-xv). Springer.

Reese, S. D. (2007). The framing project: A bridging model for media research revisited. Journal of communication, 57(1), 148-154.

Schoultz, I., \& Flyghed, J. (2019). From “we didn’t do it” to “we've learned our lesson”: Development of a typology of neutralizations of corporate crime. Critical Criminology.

Schoultz, I., \& Flyghed, J. (2021). We have been thrown under the bus: Corporate versus individual defense mechanisms against transnational corporate bribery charges. Journal of White Collar and Corporate Crime, 2(1), 24-35.

Scott, M. B., \& Lyman, S. M. (1968). Accounts. American Sociological Review, 33(1), 46-62.

Securities and Exchange Commission. (2017). In the matter of Telia Compnay AB respondent. Retrieved from

Törnqvist, N. (2017). Att göra rätt: En studie om professionell respektabilitet, emotioner och narrativa linjer bland relationsvåldsspecialiserade åklagare. Kriminologiska institutionen, Stockholms universitet.

U.S. Department of Justice. (2017). United States v. Telia Company AB Deferred Prosecution Agreement.

Walenta, J. (2020). Courtroom ethnography: Researching the intersection of law, space, and everyday practices. The Professional Geographer, 72(1), 131-138.

Yuval-Davis, N. (2007). Intersectionality, citizenship and contemporary politics of belonging. Critical Review of International Social and Political Philosophy, 10(4), 561-574.

Åkerström, M., Wästerfors, D., \& Jacobsson, K. (2016). Struggling for one's name: Defense narratives by those accused of small-time corruption. Sociological Focus, 49(2), 148-162.

Publisher's Note Springer Nature remains neutral with regard to jurisdictional claims in published maps and institutional affiliations. 